Didaché: Journal of Christian Education

Vol. 2, No. 2 (2021): 99-114

e-ISSN: 2722-8584

Published by: Sekolah Tinggi Teologi Simpson Ungaran

DOI: $10.46445 /$ djce.v2i2.430

\title{
Konselor Sekolah dalam Mengembangkan Karakter Siswa Selama Covid-19
}

\author{
Slameto \\ President University \\ Email: slameto@president.ac.id
}

\begin{abstract}
Like other educators, school counselors initially responded to the Covid-19 crisis with confusion and uncertainty, for which they needed solutions with collaboration and innovation. In schools with a framework is used to focus on the 'whole child.' MTSS supports academic growth and achievement, but also supports many other areas. MTSS is a holistic learning approach to support the growth and development of student's character and academic achievement through large-scale life changes due to the global pandemic. The pandemic prompts school counselors to turn to virtual tools to engage with and track students and families. School counselors make use of certain technological tools, but also offer some caveats about their use. During the pandemic, school counselors are expected to provide comprehensive services to students and families. Instead, they step into a leadership role that allows them to provide comprehensive virtual social-emotional and academic learning in counseling services to their students. The need for school counselors to stay connected to students during COVID-19 through providing virtual advice, providing virtual counseling (individual and/or group): trauma care, cyberbullying, managing expectations, paying attention to burnout, and managing burnout. For students' future, meet students wherever they are while respecting digital security, cyberbullying, protecting student privacy, and ensuring confidentiality; These are all important in cultivating fortitude.
\end{abstract}

Keywords: Covid-19, school counselors, MTSS, virtual services.

\begin{abstract}
Abstrak
Seperti pendidik lainnya, konselor sekolah pada awalnya menanggapi krisis Covid-19 dengan kebingungan dan ketidakpastian, untuk itu perlu solusi dengan kolaborasi dan inovasi. Di sekolah dengan kerangka kerja yang digunakan untuk berfokus pada 'seluruh anak.' MTSS mendukung tumbuh-kembang karakter dan prestasi akademik siswa, tetapi juga mendukung banyak bidang lainnya. MTSS merupakan pendekatan pembelajaran holistik untuk mendukung siswa melalui perubahan hidup berskala besar karena adanya pandemi global. Pandemi mendorong konselor sekolah untuk beralih ke alat virtual untuk terlibat dengan dan melacak siswa dan keluarga. Konselor sekolah memanfaatkan alat teknologi tertentu, tetapi juga menawarkan beberapa peringatan tentang penggunaannya. Selama pandemi, konselor sekolah diharapkan memberikan layanan komprehensif kepada siswa dan keluarga, dan alih-alih melangkah ke peran
\end{abstract}


kepemimpinan yang memungkinkan mereka untuk memberikan pembelajaran sosialemosional dan akademik yang virtual secara komprehensif dalam layanan konseling kepada siswanya. Perlunya konselor sekolah tetap terhubung dengan siswa selama covid-19 melalui pemberian nasihat virtual, penyediaan konseling virtual (individu dan/kelompok): perawatan trauma, perundungan siber, pengelolaan harapan, memperhatikan burnout, dan mengelola kejenuhan. Demi masa depan siswa, temui siswa dimanapun mereka berada dengan tetap memperhatikan keamanan digital, penindasan siber, dan perlindungan privasi siswa, serta tetap berhati-hatilah untuk memastikan kerahasiaan; Itu semua penting dalam menumbuhkan ketabahan.

Kata Kunci: Covid-19, konselor sekolah, MTSS, layanan virtual.

\begin{tabular}{ll}
\hline Article History Received: July 30, $2021 \quad$ Revised: Sept. 08, 2021 & Accepted: Sept. 15, 2021 \\
This is an open access article under the CC BY-SA license cc) (2)
\end{tabular}

\section{Pendahuluan}

Pandemi Covid-19 telah berdampak luas pada operasional sekolah di mana interaksi tatap muka telah menjadi virtual dengan belajar dari rumah (Diana, Darmawan, \& Br Simamora, 2021; Hutapea, 2020; Pramana et al., 2021). Siswa harus menyesuaikan diri terhadap pembelajaran virtual dengan mengalami stres, kecemasan, dan bahkan ada yang sampai depresi; memiliki ketakutan belajar di rumah dan khawatir tentang prestasi akademik mereka di samping akan tertular Covid-19 (Fitria \& Ifdil, 2020; Oktawirawan, 2020). Mereka juga memiliki hambatan dalam mengakses sumber daya yang bermanfaat atas masalah mereka, misalnya, layanan konseling sekolah (Kaznosky, 2021).

Sebagai akibat dari Covid-19, hampir 50\% siswa dilaporkan mengalami depresi sehingga sulit untuk berfungsi sebagai peserta didik sebagaimana mestinya. Kecemasan yang dihasilkan mengganggu keberhasilan akademik, serta sosialisasi mereka. Dalam kondisi seperti itu, beberapa sekolah memilih untuk melakukan tatap muka, daring, dan atau menggunakan versi hibrida, ketiganya menghadirkan tantangan bagi konselor/guru pembimbing. Seorang konselor sekolah menempati peran penting selama pandemi global ini (St. Bonaventure University's, 2020). Peran itu seharusnya adalah untuk mendengarkan siswa, membantu siswa mengubah tujuan mereka menjadi tindakan dan mendukung kesehatan mental siswa selama masa-masa sulit. Seorang konselor atau guru pembimbing mestinya dapat membantu mendorong siswa dengan tetap terhubung secara daring, dengan mempromosikan tujuan akademik mereka - termasuk mendukung tumbuh-kembang karakter dan prestasi akademik siswa - serta bersama-sama menciptakan masa depan yang lebih baik. Tantangannya adalah 
bagaimana agar para konselor/guru pembimbing dapat mewujudkannya. Seorang konselor sekolah bertindak sebagai pembimbing sekaligus advokat untuk kesejahteraan siswa dan kemajuan akademik. Para profesional ini memiliki tanggung jawab unik untuk memperhatikan pengalaman siswa di sekolah sambil juga mempertanyakan bagaimana pengalaman mereka di luar kelas memengaruhi pendidikan dan kesehatan mental mereka.

Pandemi global telah mempengaruhi cara siswa menjalani pendidikan di rumah dengan beberapa perasaan: kecemasan, kesedihan, keterputusasan yang mereka miliki begitu lama (Kaznosky, 2021) dan yang akan meningkat. Terkait dengan kondisi siswa seperti itu, perlulah kita fahami bahwa konselor sekolah memiliki tugas dan tanggung jawab (St. Bonaventure University's, 2020) antara lain seperti berikut ini: 1) berusaha untuk mengenal siswa yang mereka bimbing; 2) menasihati siswa tentang kehidupan akademik, sosial dan emosional mereka,; 3) menyediakan layanan perencanaan individual siswa untuk memajukan tujuan akademiknya; 4) memberikan konseling kepada siswa tentang kebijakan pendidikan, sosial dan pentingnya sekolah dan menawarkan lokakarya dan seminar pembelajaran efektif dalam kondisi sulit; 5) menjaga komunikasi dengan orang tua, guru, administrator, dan agen eksternal mengenai keberhasilan akademik dan kesejahteraan siswa secara keseluruhan; 6) memberikan umpan balik dan mengambil tindakan untuk menciptakan solusi yang meningkatkan kebutuhan akademik siswa secara individu; 7) membantu mengidentifikasi siswa yang mungkin memerlukan layanan intensif dan berkoordinasi dengan spesialis kesehatan perilaku; 8) membantu siswa dan orang tua dalam memahami kebijakan sekolah; 9) memberikan konseling singkat untuk mengatasi masalah sosial dan emosional siswa tetapi juga merujuk siswa ke spesialis kesehatan perilaku bila diperlukan; 10) berkolaborasi dengan spesialis kesehatan perilaku dalam mengembangkan sistem dukungan siswa di sekolah; dan 11) mempertahankan kehadiran di kegiatan siswa dan acara sekolah yang sesuai (termasuk kehadiran daring dalam acara sekolah virtual). Pandemi mendorong konselor sekolah untuk beralih ke platform virtual untuk terlibat dengan dan melacak siswa dan keluarga (Strear, Duffy, \& Sunde, 2021). Konselor sekolah mengakui tersedianya alat/platform teknologi tertentu, tetapi juga menawarkan beberapa peringatan (terkait etika konseling) tentang penggunaannya.

Sebelum konselor sekolah dapat mempersiapkan siswa untuk masa depan, mereka harus terlebih dahulu mempersiapkan diri dengan sumber daya dan alat/moda yang diperlukan untuk memberikan layanan yang bernilai ke- 
pada siswa mereka selama Covid-19 dan setelahnya. Dengan mempelajari dan memahami lebih lanjut tentang bagaimana konselor atau guru pembimbing sekolah dapat membuat layanan yang beda karena tuntutan pembelajaran dari rumah, lebih tepat sasaran dalam kehidupan siswa selama Covid-19 dan seterusnya mampu mempromosikan keberhasilan siswa.

\section{Metode}

Tulisan ini merupakan literature review yaitu sebuah metode yang sistematis, eksplisit dan reprodusibel untuk melakukan identifikasi, evaluasi dan sintesis terhadap karya-karya hasil penelitian dan/hasil pemikiran yang sudah dihasilkan oleh para peneliti dan praktisi. Literature review bertujuan untuk membuat analisis dan sintesis terhadap pengetahuan yang sudah ada terkait topik yang dikaji untuk menemukan ruang kosong bagi penelitian yang dilakukan. Tulisan ini bertujuan untuk menjawab pertanyaan-pertanyaan praktis dengan pemahaman terhadap apa yang sudah dihasilkan oleh penelitian terdahulu (Okoli \& Schabram, 2010). Review yang penulis lakukan termasuk narrative overview/unsystematic review (A. Ramdhani, Ramdhani, \& Amin, 2014; M. A. Ramdhani \& Ramdhani, 2013) melalui tahapan: memilih topik yang akan ditinjau, melacak dan memilih artikel yang relevan, melakukan analisis dan sintesis literatur, dan mengorganisasi penulisan.

\section{Hasil}

\section{Kerangka MTSS (Multi-Tiered System of Supports)}

Multi-Tiered System of Supports (MTSS) adalah kerangka kerja yang digunakan banyak sekolah untuk memberikan dukungan yang ditargetkan kepada siswa yang kesulitan. Ini berfokus pada 'seluruh siswa.' MTSS mendukung tumbuh-kembang karakter dan prestasi akademik siswa, tetapi juga mendukung banyak bidang lainnya, termasuk perilaku, kebutuhan sosial dan emosional dan ketidak-hadiran. Artinya, MTSS merupakan pendekatan pembelajaran holistik untuk mendukung siswa melalui perubahan hidup berskala besar seperti adanya pandemi global ini. Seorang konselor sekolah dapat menggunakan kerangka kerja ini untuk meningkatkan pengalaman siswa mereka baik di dalam maupun di luar kelas (St. Bonaventure University's, 2020).

Konselor sekolah adalah pemangku kepentingan dalam pengembangan dan implementasi MTSS (American School Counselor Association, 2021), terma- 
suk namun tidak terbatas pada respon terhadap intervensi dan intervensinya serta dukungan perilaku positif yang responsif. Konselor sekolah menyelaraskan pekerjaannya dengan MTSS melalui pelaksanaan program konseling sekolah yang komprehensif, dirancang untuk mempengaruhi perkembangan siswa dalam domain akademik (prestasi), domain karir (eksplorasi dan pengembangan karir) dan domain sosial/emosional (perilaku).

MTSS menawarkan peluang bagi konselor sekolah untuk memiliki dampak yang bertahan lama pada keberhasilan akademik siswa dan pengembangan perilaku sambil mengintegrasikan kerangka kerja dalam program konseling sekolah. Penerapan MTSS selaras dengan peran konseling sekolah di semua jenjang dan tingkat kelas dan dapat digunakan di berbagai domain seperti akademik, karier dan/atau perkembangan sosial/emosional. Konselor sekolah pada era Covid-19 ini seharusnya bekerja secara kolaboratif dengan pendidik lain untuk menghilangkan hambatan sistemik bagi semua siswa dan menerapkan dukungan pembelajaran khusus yang membantu keberhasilan akademik dan perilaku. Kemampuan beradaptasi dan penyampaian program, pendampingan sosial emosional, komunikasi dengan orang tua, pemanfaatan perangkat teknologi, aksesibilitas dan pelatihan internet, dan keterlibatan/kehadiran staf serta kehadiran dan partisipasi siswa (Hunter, 2021).

\section{Perlunya Konselor Sekolah Tetap Terhubung dengan Siswa Selama Covid-19}

Konselor sekolah bekerja dengan siswa dan keluarga untuk menghilangkan atau meminimalkan hambatan sosial, emosional, dan akademik untuk pendidikan. Hambatan atau tantangan ini diperparah ketika variabel seperti perubahan peran, pergeseran dalam pengaturan kerja, dan pandemi Covid-19 hadir (Hunter, 2021). Covid-19 telah mengubah cara konselor sekolah berinteraksi dengan siswa mereka. Salah satu langkah terpenting yang harus dilakukan konselor sekolah untuk memengaruhi siswa selama pandemi global adalah menemukan cara untuk tetap terhubung dan terlibat di platform virtual. Ada banyak cara konselor atau guru pembimbing mendorong hubungan dengan siswa mereka (High Focus Centers, 2021; St. Bonaventure University's, 2020).

\section{Memberikan Nasihat Virtual}

Seorang konselor atau guru pembimbing dapat menggunakan teknologi dan platform daring untuk terus memberikan saran kepada siswa dengan cara berikut: 1) ikuti pedoman sekolah saat mengakses catatan siswa secara daring; 2) 
dapat diakses oleh siswa secara daring melalui email, telepon, dan platform daring lainnya; 3) ikuti rencana komunikasi yang digariskan oleh sekolah;4) patuhi peraturan sekolah dan saat berkomunikasi secara daring; dan 5) menawarkan sumber daya daring kepada siswa dan keluarga mereka untuk meningkatkan perkembangan akademik, karir, dan emosional mereka (Cano \& Meneses, 2012).

\section{Menyediakan Konseling Virtual}

Seorang konselor atau guru pembimbing dapat menggunakan teknologi dan platform daring untuk terus memberikan konseling virtual kepada siswa dengan cara berikut: 1) gunakan platform daring yang direkomendasikan oleh sekolah; 2) kenali persyaratan seputar kerahasiaan dalam pengaturan virtual; dan 3) tetapkan batasan dengan siswa dan keluarga mereka sebelum terlibat dalam konseling virtual (Cano \& Meneses, 2012).

Trauma Individu dan Konseling Sekolah: Pentingnya Perawatan Berdasarkan Informasi Trauma

Seperti apa masa depan konselor atau guru pembimbing setelah pandemi virus corona dan penutupan/lock down nasional? Seorang konselor atau guru pembimbing bersedia untuk membantu setiap siswa. Namun, konselor sekolah harus dilatih untuk memenuhi kebutuhan unik setiap siswa. Konselor sekolah dapat menggunakan praktik yang diinformasikan tentang trauma untuk memahami dampak SARA dan bentuk ketidakadilan lainnya terhadap siswa mereka dan dilengkapi dengan sumber daya yang diperlukan untuk mendengarkan dan menanggapi siswa mereka (High Focus Centers, 2021).

\section{Memberikan Perawatan Trauma}

Seorang konselor atau guru pembimbing sekolah memiliki peran unik dalam sistem sekolah untuk memberikan perawatan berdasarkan informasi trauma kepada siswa. Seorang konselor atau guru pembimbing dapat menciptakan lingkungan yang peka terhadap trauma bagi siswa dengan melakukan hal berikut: 1) mengenali tanda-tanda trauma pada siswa; 2) fahami bahwa trauma tidak memprediksi kegagalan individu; 3) fokus pada ketahanan dan kekuatan siswa; 4) jangan membuat siswa trauma kembali; 5) ciptakan komunikasi terbuka dan komunitas sekolah yang peka terhadap trauma; 6) mendorong sekolah untuk terlibat dengan jaringan sosial yang positif di masyarakat; 7) mendorong pembelajaran sosial dan emosional di sekolah; 8) mempromosikan hubungan yang 
aman, stabil dan terpelihara dengan siswa; 9) memberikan sumber daya dan informasi tambahan kepada siswa; 10) mendidik anggota staf tentang efek trauma; 11) minta staf untuk merujuk siswa yang rentan ke konselor atau guru pembimbing; dan 12) rujuk siswa ke spesialis kesehatan perilaku bila perlu (Martinez Jr, Williams, \& Green, 2019).

\section{Keamanan Digital, Penindasan Siber, dan Perlindungan Privasi Siswa}

Lebih banyak anak menghabiskan waktu daring di tengah pandemi global. Hal ini sangat membantu bagi konselor bimbingan untuk memberikan penyegaran tentang keamanan digital, cyberbullying, dan pentingnya perlindungan privasi. Melarang teknologi bukanlah jawabannya, melainkan mengajar anakanak untuk menjadi warga digital yang baik. Seorang konselor atau guru pembimbing dapat mendidik siswa tentang cara menavigasi internet dengan aman daripada menghindarinya sama sekali (McInerney \& McKlindon, 2014) untuk empat kepentingan berikut:

\section{Keamanan Digital}

Siswa harus diajari cara tetap aman saat daring. Konselor sekolah dapat mendorong keamanan digital melalui pendidikan dan mengajari siswa mereka hal-hal berikut: 1) tetapkan standar untuk apa yang dapat diterima dan tidak dapat dilakukan secara daring; 2) ajari siswa untuk tidak membagikan informasi pribadi yang sensitif secara daring; 3) diskusikan dampak media sosial pada kesehatan mental dan kesejahteraan dan buat parameter media sosial; 4) ciptakan jalur komunikasi terbuka dan dorong anak-anak untuk melaporkan masalah yang mereka hadapi secara daring dengan konselor atau guru pembimbing; dan 5) minta orang tua untuk berbicara dengan anak-anak mereka tentang penggunaan internet mereka.

\section{Perundungan Siber}

Dengan ruang kelas fisik digantikan oleh ruang kelas virtual, lebih banyak siswa berinteraksi satu sama lain secara daring. Interaksi daring terjadi di belakang layar dan sehingga dapat menyebabkan berkurangnya sensor dan meningkatnya kasus cyberbullying. Konselor sekolah dapat mendorong penerapan intervensi dan program pencegahan cyberbullying untuk memerangi bullying daring selama pandemi global. Studi menunjukkan bahwa program ini dapat mengurangi tindakan cyberbullying sekitar 10\%-15\% dan korban cyberbullying sekitar 
$14 \%$. Seorang konselor sekolah dapat membantu mencegah cyberbullying dengan mengambil tindakan berikut: 1) tanggapi cyberbullying dengan serius; 2) kenali situs jejaring sosial, bahasa gaul, dan istilah yang biasa digunakan siswa; 3) kenali isyarat sosial dari siswa yang mungkin mengalami intimidasi; 4) dorong siswa untuk mengambil tangkapan layar dan melaporkan kejadian cyberbullying; 5) bicaralah dengan siswa yang bertanggung jawab dalam kasus cyberbullying; dan 6) undang orang tua ke percakapan dan bagikan contoh dan kebijakan sekolah.

Perlindungan Privasi

Pendidik yang telah memindahkan pengajarannya secara daring kini menggunakan media baru seperti kamera video dan platform pesan instan untuk berkomunikasi dengan siswa. Seorang guru, konselor bimbingan, dan siswa harus diberi informasi yang sama tentang asuransi kesehatan, dan etika seputar penggunaan platform digital (Rastrick, 2020).

\section{Masa Depan bagi Siswa}

Apakah aman untuk membuka kembali sekolah di zona hijau? Jika demikian, seperti apa pembukaannya kembali? Sebagai pendidik, pemimpin sekolah, atau konselor bimbingan, penting untuk tetap mendapatkan informasi dan mempersiapkan tahun ajaran secara daring dan luring. Meskipun sekolah mungkin mulai dibuka kembali, pakar kesehatan masyarakat mengatakan bahwa jika setelah sekolah dibuka kembali, mereka harus merencanakan kemungkinan penutupan jika terjadi wabah virus corona lebih lanjut. Akibatnya, pemimpin sekolah harus siap dengan segala kemungkinan.

\section{Konseling Selama Covid 19: Tips untuk Konselor Sekolah}

Covid-19 telah membawa tantangan bagi banyak industri, pendidikan dan tidak terkecuali konseling. Sesi teleterapi berbeda dengan sesi tatap muka. Konselor sekolah mungkin berjuang untuk membangun hubungan dan membuat klien tetap terlibat (High Focus Centers, 2021). Berikut beberapa strategi yang efektif untuk digunakan saat memberikan konseling kepada siswa secara virtual:

Gambar 1. Strategi Konseling Secara Virtual

\begin{tabular}{ll}
\hline \multicolumn{1}{c}{ Strategi } & \multicolumn{1}{c}{ Deskripsi } \\
\hline Temui Siswa di & $\begin{array}{l}\text { Mulailah dengan mengenali bahwa siswa yang menghadapi } \\
\text { Manapun }\end{array}$ \\
Mereka Berada & $\begin{array}{l}\text { rang fokus di rumah, jadi konselor mungkin tidak bisa tetap } \\
\text { fokus dalam sesi konseling. Hal itu perlu diterima dan jangan }\end{array}$ \\
\hline
\end{tabular}




\begin{tabular}{|c|c|}
\hline & $\begin{array}{l}\text { mencoba memaksakan diri untuk menyelesaikan terlalu ba- } \\
\text { nyak. Buat sesi tetap ringan dan temukan cara untuk terhubung } \\
\text { ke siswa. Cobalah berbagi perjuangan yang dalami guru itu } \\
\text { sendiri selama pandemi. Lakukan identifikasi sasaran baru } \\
\text { untuk sesi virtual jika diperlukan. Saat mengidentifikasi tujuan } \\
\text { baru, pastikan untuk menetapkan garis waktu yang realistis } \\
\text { untuk mencapainya, dan periksa secara teratur. }\end{array}$ \\
\hline $\begin{array}{l}\text { Berhati-hatilah } \\
\text { untuk } \\
\text { Memastikan } \\
\text { Kerahasiaan }\end{array}$ & $\begin{array}{l}\text { Salah satu tantangan terbesar dari sesi virtual adalah memas- } \\
\text { tikan kerahasiaan siswa. Lebih sulit untuk memastikan mereka } \\
\text { berada di ruang pribadi saat di rumah. Mulailah setiap sesi } \\
\text { virtual dengan ulasan tentang apa itu kerahasiaan. Tanyakan } \\
\text { kepada klien dan orang tua/wali mereka bagaimana mereka } \\
\text { dapat memastikan kerahasiaan; langsung menanyakan apakah } \\
\text { mereka berada di ruang pribadi. Ini juga merupakan ide yang } \\
\text { baik untuk mengembangkan memo yang mendefinisikan kera- } \\
\text { hasiaan dan meninjaunya dengan orang tua dan siswa. }\end{array}$ \\
\hline $\begin{array}{l}\text { Melakukan } \\
\text { Penilaian Risiko } \\
\text { yang Efektif }\end{array}$ & $\begin{array}{l}\text { Mungkin lebih sulit untuk menilai risiko tindakan pembunuhan } \\
\text { atau bunuh diri ketika bekerja dengan klien secara virtual. Orang } \\
\text { tua perlu dilibatkan dalam proses ini karena mereka dapat } \\
\text { memantau anak-anak di rumah. Berikut adalah beberapa tips } \\
\text { untuk penilaian risiko: 1) ajukan pertanyaan yang tepat. tanya- } \\
\text { kan langsung kepada siswa apakah mereka berniat menyakiti } \\
\text { diri sendiri atau orang lain. gunakan kuis penilaian risiko bunuh } \\
\text { diri dan/atau pembunuhan sesuai kebutuhan; 2) biasakan diri } \\
\text { anda dengan riwayat klien. apakah mereka pernah melakukan } \\
\text { percobaan bunuh diri atau tindakan disiplin dari sekolah? } \\
\text { berapa lama mereka memiliki ide pembunuhan atau bunuh } \\
\text { diri? seberapa parah idenya?; 3) memanfaatkan umpan balik } \\
\text { dari orang lain - orang tua, guru, dan staf; 4) susun intervensi } \\
\text { sejak awal dan kembangkan rencana keselamatan yang kom- } \\
\text { prehensif. pastikan siswa dan orang tua memahami tindakan } \\
\text { apa yang harus anda ambil untuk mengurangi risiko. }\end{array}$ \\
\hline Kelola Harapan & $\begin{array}{l}\text { Konseling virtual tidak akan sama dengan sesi tatap muka. } \\
\text { Pastikan konselor menetapkan harapan yang realistis sejak awal. } \\
\text { Bila memungkinkan, mintalah klien memberikan masukan ten- } \\
\text { tang harapan. Perhatikan batas sesi virtual dan perbedaan antara } \\
\text { sesi virtual dan tatap muka. }\end{array}$ \\
\hline $\begin{array}{l}\text { Konseling } \\
\text { Individu }\end{array}$ & $\begin{array}{l}\text { Konseling individu virtual bisa sangat mirip dengan sesi tatap } \\
\text { muka satu lawan satu. Respon siswa dapat bervariasi dari ter- } \\
\text { libat dan fokus pada tujuan penyembuhan, hingga diam dan } \\
\text { menarik diri. Mungkin lebih sulit bagi siswa untuk fokus dan } \\
\text { terlibat di layar hp atau komputer. }\end{array}$ \\
\hline $\begin{array}{l}\text { Konseling } \\
\text { Kelompok }\end{array}$ & $\begin{array}{l}\text { Konseling kelompok virtual juga bisa mirip dengan tatap muka, } \\
\text { tetapi dengan beberapa kendala tambahan. Kelompok berjalan }\end{array}$ \\
\hline
\end{tabular}




\begin{tabular}{|c|c|}
\hline & $\begin{array}{l}\text { lebih baik dengan lebih dari satu fasilitator. Sangat membantu } \\
\text { jika ada teman lain yang hadir untuk memantau aktivitas klien } \\
\text { dan menonaktifkan fitur video, mikrofon, atau obrolan sesuai } \\
\text { kebutuhan. Tetapkan aturan yang jelas untuk membantu } \\
\text { mengelola grup di platform virtual. }\end{array}$ \\
\hline $\begin{array}{l}\text { Perhatikan } \\
\text { Burnout }\end{array}$ & $\begin{array}{l}\text { Burnout adalah keadaan kelelahan kronis dan kurangnya moti- } \\
\text { vasi yang disebabkan oleh stres berkepanjangan. Konselor dan } \\
\text { klien sama-sama berisiko mengalami burnout. Penting untuk } \\
\text { mempelajari tanda-tanda peringatan dan secara aktif mengelola } \\
\text { stres. Tanda-tanda peringatan kelelahan meliputi: depresi, ke- } \\
\text { lelahan, pandangan negatif/sinisme, kurangnya kasih sayang } \\
\text { atau empati, takut pergi bekerja, marah/mudah tersinggung, } \\
\text { dan merasa tidak bisa melakukan pekerjaan dengan baik/ } \\
\text { efektif. }\end{array}$ \\
\hline $\begin{array}{l}\text { Mengelola } \\
\text { Kejenuhan }\end{array}$ & $\begin{array}{l}\text { Jika merasa seperti sedang mengalami burnout, atau hanya } \\
\text { ingin mencegahnya, berikut adalah beberapa strategi yang sehat } \\
\text { untuk digunakan: 1) tetapkan batasan di tempat kerja; 2) beri- } \\
\text { stirahatlah secara teratur, jangan bekerja lembur, katakan tidak } \\
\text { pada tugas yang tidak dapat anda lakukan; 3) temukan keseim- } \\
\text { bangan antara pekerjaan dan kehidupan; 4) jangan bekerja di } \\
\text { luar jam kerja normal kecuali benar-benar diperlukan dan hin- } \\
\text { dari kebiasaan ini; 5) restrukturisasi lingkungan anda untuk } \\
\text { membantu anda menjadi lebih efektif di tempat kerja; 6) saat } \\
\text { bekerja dari rumah, buatlah ruang terpisah sehingga anda dapat } \\
\text { memiliki batasan yang jelas antara kehidupan kerja dan kehi- } \\
\text { dupan rumah. }\end{array}$ \\
\hline $\begin{array}{l}\text { Latih Perawatan } \\
\text { Diri Setiap Hari }\end{array}$ & $\begin{array}{l}\text { Jaga kebutuhan spiritual, fisik, emosional, pribadi, profesional, } \\
\text { dan psikologis Anda melalui praktik perawatan diri secara tera- } \\
\text { tur. Mengidentifikasi dan memanfaatkan dukungan di dalam } \\
\text { dan di luar pekerjaan. Misalnya, Anda mungkin meminta ban- } \\
\text { tuan rekan kerja atau meminta teman sekamar Anda untuk } \\
\text { melakukan tugas yang tidak sempat Anda selesaikan. }\end{array}$ \\
\hline $\begin{array}{lr}\text { Akses } & \text { Sumber } \\
\text { Daya } & \text { Yang } \\
\text { Tersedia } & \end{array}$ & $\begin{array}{l}\text { Identifikasi sumber daya yang disediakan oleh pemberi kerja } \\
\text { atau komunitas Anda dan akseslah sesuai kebutuhan. Misalnya, } \\
\text { jika pimpinan sekolah menawarkan konseling melalui Program } \\
\text { Bantuan Karyawan, manfaatkan itu. }\end{array}$ \\
\hline $\begin{array}{l}\text { Mengembangkan } \\
\text { Kesadaran Diri }\end{array}$ & $\begin{array}{l}\text { Terus-menerus menilai tingkat stres dan rasa sejahtera Anda } \\
\text { untuk memastikan Anda mengalami kelelahan sebelum } \\
\text { menjadi lebih buruk. }\end{array}$ \\
\hline $\begin{array}{l}\text { Tahu Kapan } \\
\text { Harus Membuat } \\
\text { Rujukan }\end{array}$ & $\begin{array}{l}\text { Sebagai seorang konselor, Anda ingin melakukan semua yang } \\
\text { Anda bisa untuk membantu siswa Anda. Terkadang itu berarti } \\
\text { merujuk mereka ke tingkat perawatan yang lebih tinggi. Inilah } \\
\text { cara mengetahui apakah rujukan mungkin diperlukan. }\end{array}$ \\
\hline
\end{tabular}




\begin{tabular}{ll}
\hline $\begin{array}{l}\text { Siswa Itu Dalam } \\
\text { Krisis }\end{array}$ & $\begin{array}{l}\text { Ketika seorang siswa secara aktif mau bunuh diri atau pem- } \\
\text { bunuhan, ini adalah situasi krisis dan membutuhkan bantuan } \\
\text { darurat. Jika klien Anda berniat untuk bunuh diri atau pembu- } \\
\text { nuhan dan/atau memiliki rencana untuk melakukannya, hu- } \\
\text { bungi unit gawat darurat setempat atau penegak hukum. }\end{array}$ \\
\hline $\begin{array}{l}\text { Siswa } \\
\text { Membuat }\end{array}$ & $\begin{array}{l}\text { Kaji gejala siswa dan kemajuannya menuju tujuan penyembuh- } \\
\text { an di setiap sesi. Jika mereka tidak membuat kemajuan setelah } \\
\text { Semakin Buruk } \\
\text { beberapa sesi, atau jika gejalanya memburuk, ini bisa menunjuk- } \\
\text { kan bahwa tingkat perawatan yang lebih tinggi diperlukan. Per- } \\
\text { timbangkan rujukan ke rawat jalan intensif, rawat inap parsial, } \\
\text { atau program rawat inap. Klien akan mendapat manfaat dari } \\
\text { peningkatan struktur program ini. Setelah mereka membuat ke- } \\
\text { majuan yang cukup, mereka dapat melanjutkan sesi rawat jalan. }\end{array}$ \\
\hline
\end{tabular}

Sumber: (Ahmed \& Firdous, 2020; Bastomi, 2019; Pincus, Hannor-Walker, Wright, \& Justice, 2020; Strear et al., 2021; Tanti, 2021; Wong, Ming, Maslow, \& Gifford, 2020)

\section{Pembahasan}

MTSS, termasuk respons terhadap intervensi merupakan perilaku positif oleh konselor sekolah. Intervensi dan dukungan, sebagai kerangka kerja diterapkan secara luas di sekolah untuk mengatasi kebutuhan/masalah akademik dan perilaku semua siswa. Konselor sekolah digambarkan sebagai intervensi, fasilitator dan pendukung penerapan MTSS; dalam memfasilitasi program konseling sekolah yang komprehensif menunjukkan relevansi positifnya dengan inisiatif dan pentingnya misi sekolah (Ziomek-Daigle, Goodman-Scott, Cavin, \& Donohue, 2016).

Pandemi global telah mengungkapkan pentingnya dan vitalnya konselor atau guru pembimbing yang terlatih bagi siswa. Brennan seorang pakar pendidikan dari Forbes mengatakan bahwa konselor atau guru pembimbing sekolah berada di garis depan untuk mendukung generasi muda bangsa saat mereka bergerak melalui perjalanan pendidikan mereka (St. Bonaventure University's, 2020). Barnard melanjutkan dengan mengatakan, kelangsungan tenaga kerja dan prospek ekonomi negara bergantung pada masyarakat terdidik yang telah membuat pilihan bijak setelah sekolah. Cara yang paling dapat diandalkan untuk memastikan ini adalah dengan mendukung konselor atau guru pembimbing sekolah.

Penggunaan teknologi informasi dan komunikasi digital (TIK) telah memungkinkan banyak profesional untuk terus memberikan layanan mereka selama pandemi Covid-19. Hasil penelitian Dores, Geraldo, Carvalho, \& Barbosa (2020) menunjukkan bahwa para profesional ini terus memberikan layanan me- 
reka karena telah mengadopsi TIK. Dibandingkan dengan intervensi tatap muka, diakui bahwa tindakan pencegahan dan pengetahuan tambahan diperlukan untuk menggunakan teknologi tersebut. Penggunaan TIK diakui sebagai tindakan positif, memenuhi kepatuhan klien, dan membuahkan hasil yang positif.

Konselor sekolah yang terlatih dapat membantu mengatasi masalah ketakutan siswa akan ketidak-pastian dan menginspirasi siswa mereka untuk terus berjuang demi kehidupan akademik dan profesional yang memuaskan di masa depan. Seorang konselor atau guru pembimbing benar-benar berada di "garis depan" dalam hal membangun kembali ekonomi bangsa dan membimbing kaum muda di masa depan pasca-pandemi.

Tantangan ini hanya akan terjawab dengan pengembangan program bimbingan konseling yang komprehensif dalam kerangka MTSS. Pendekatan MTSS holistik terbukti meningkatkan kinerja konseling sekolah dalam era pandemic Covid 19. Di masa depan era normal ataupun pasca pandemi, seorang konselor dapat mengharapkan memprakasai perubahan berikut: 1) peningkatan platform dan layanan konseling daring; 2) fokus yang lebih besar pada praktik dan meditasi berbasis kesadaran untuk kesehatan mental; 3) konseling individu untuk siswa yang rentan terhadap masalah kesehatan mental; 4) perhatian yang lebih besar diberikan pada privasi dan kerahasiaan daring; 5) konselor mencari spesialis perilaku lain untuk membantu siswa; dan 6) konsultasi dengan pakar dari perguruan tinggi yang komprehensif secara daring (High Focus Centers, 2021).

\section{Implikasi Bagi Pendidikan Kristen}

Implikasi untuk penelitian masa depan (Okoli \& Schabram, 2010) antara lain: berapa persentase siswa yang tidak dapat berkomunikasi dengan konselor sekolah mereka secara virtual karena tidak memiliki akses internet, bekerja sepanjang waktu, harus menjaga saudara-saudara mereka, tidak memiliki kehidupan rumah yang baik, orang tua mereka tidak ingin berkomunikasi dengan konselor sekolah, tidak ingin anggota keluarga mereka untuk mendengar mereka membahas tentang diri sendiri kepada konselor sekolah. Selain itu juga seberapa besar kemampuan konselor sekolah untuk menyukseskan program BK yang komprehensif dengan kerangka MTSS diera Covid 19 ini?

Pendidik Kristen sering berjuang untuk memotivasi siswa di era pandemi. Ada krisis besar di antara mereka untuk mengembangkan kemampuan mengelola emosi yang kuat dan merespons secara efektif situasi stres, yang mempengaruhi pengembangan karakter menuju kedewasaan mereka. Itu perlu untuk 
memupuk ketekunan dan semangat untuk tujuan jangka panjang, yang disebut ketabahan (Listio, Simanjuntak, Butarbutar, \& Setyowati, 2020)meme-rangi dampak pandemi Covid-19 pendidikan Kristen harus memupuk keta-bahan. Penelitian Benedetta dan Objantoro (2020) menunjukkan bahwa dalam konseling Kristen diperlukan penanaman pemahaman dan motivasi yang men-dorong daya juang melawan pandemi. Itu artinya pendidik Kristen yang ber-peran sebagai konselor dapat turut membangun pemahaman dan motivasi yang melahirkan daya juang di masa pandemi Covid-19.

\section{Kesimpulan}

Seperti pendidik lainnya, konselor sekolah pada awalnya menanggapi krisis Covid-19 dengan kebingungan dan ketidakpastian, yang diikuti dengan kolaborasi dan inovasi. Di sekolah dengan kerangka kerja yang digunakan untuk memberikan dukungan yang ditargetkan kepada siswa yang kesulitan, tetapi juga berfokus pada 'seluruh anak.' MTSS mendukung pertumbuhan dan prestasi akademik, tetapi juga mendukung banyak bidang lainnya. MTSS merupakan pendekatan pembelajaran holistik untuk mendukung pengembangan karakter siswa melalui perubahan hidup berskala besar seperti adanya pandemi global.

Selama pandemi, konselor sekolah diharapkan memberikan layanan komprehensif kepada siswa dan keluarga, dan alih-alih melangkah ke peran kepemimpinan yang memungkinkan mereka untuk memberikan pembelajaran sosial-emosional dan akademik yang komprehensif, virtual, dan dalam layanan konseling kepada siswanya. Perlunya konselor sekolah tetap terhubung dengan siswa selama Covid-19 melalui pemberian nasihat virtual, penyediaan konseling virtual (individu dan/kelompok) perawatan trauma, perundungan siber, pengelolaan harapan, memperhatikan burnout, dan mengelola kejenuhan. Demi masa depan siswa, temui siswa di manapun mereka berada dengan tetap memperhatikan keamanan digital, penindasan siber, dan perlindungan privasi siswa, serta tetap berhati-hatilah untuk memastikan kerahasiaan.

Konselor sekolah memerlukan dukungan untuk menyesuaikan layanan mereka, oleh karena itu, disarankan untuk tidak menugaskan konselor sekolah untuk tugas-tugas administratif, seperti melacak kehadiran dan bantuan teknologi pembelajaran (e-learning). Selain itu menyediakan pelatihan yang relevan untuk konselor sekolah; jika dimungkinkan menambah jumlah konselor sehingga tercapai rasio siswa dan konselor yang lebih kecil. Disamping itu konse- 
lor sekolah Kristen perlu ikut mengupayakan agar sekolah tempat bekerjanya memupuk dan mengembangkan ketabahan.

\section{Daftar Rujukan}

Ahmed, A., \& Firdous, H. (2020). The Transformational Effects of COVID-19 Pandemic on Guidance and Counseling. International Journal of Advance Research and Innovative Ideas in Education, 6(6), 172-179. https:/ / doi.org/16.0415/IJARIIE-13042

American School Counselor Association. (2021). The School Counselor and Multitiered System of Supports. Retrieved September 8, 2021, from American School Counselor Association (ASCA) website: https:// www.schoolcounselor.org/Standards-Positions/PositionStatements / ASCA-Position-Statements/The-School-Counselor-andMultitiered-System-of-Sup

Bastomi, H. (2019). Cyber Konseling: Sebuah Model Konseling Pada Konteks Masyarakat Berbasis Online. Konseling Edukasi: Journal of Guidance and Counseling, 3(1). https:/ / doi.org/10.21043/KONSELING.V3I1.4993

Cano, E. V., \& Meneses, E. L. (2012). Virtual Tutoring and Counseling in Schools. ISRN Education, 2012, 1-8. https:/ / doi.org/10.5402/2012/816590

Diana, R., Darmawan, I. P. A., \& Br Simamora, E. S. (2021). Kerjasama Orang Tua Dan Guru Dalam Pembelajaran Paud Di Masa Pandemi Covid-19. VOX DEI: Jurnal Teologi Dan Pastoral, 2(1), 1-16. https:/ / doi.org/10.46408/vxd.v2i1.42

Dores, A. R., Geraldo, A., Carvalho, I. P., \& Barbosa, F. (2020). The Use of New Digital Information and Communication Technologies in Psychological Counseling during the COVID-19 Pandemic. International Journal of Environmental Research and Public Health, 17(20), 7663. https:// doi.org/10.3390/ijerph17207663

Fitria, L., \& Ifdil, I. (2020). Kecemasan remaja pada masa pandemi Covid -19. Jurnal EDUCATIO: Jurnal Pendidikan Indonesia, 6(1), 1-4. https:// doi.org/10.29210/120202592

High Focus Centers. (2021, January 18). Tips for Counseling Students During COVID-19. Retrieved September 8, 2021, from High Focus Centers website: https:// highfocuscenters.pyramidhealthcarepa.com/counseling-duringcovid-tips-for-school-counselors/

Hunter, T. (2021). Virtual School Counseling Amid the COVID-19 Pandemic (Liberty University). Liberty University. Retrieved from 
https:// digitalcommons.liberty.edu/doctoral/2978

Hutapea, R. H. (2020). Kreativitas Mengajar Guru Pendidikan Agama Kristen Di Masa Covid-19. Didache: Journal of Christian Education, 1(1), 1. https://doi.org/10.46445/djce.v1i1.287

Kaznosky, K. (2021). Virtual School Counseling During the COVID-19 Pandemic. Undergraduate Research Symposium. ODU Digital Commons. Retrieved from https:// digitalcommons.odu.edu/undergradsymposium/2021/interdiscip linary $/ 25$

Listio, S., Simanjuntak, H. P., Butarbutar, M., \& Setyowati, V. (2020). Cultivating Grit for Students Career Maturity: An Overview of Christian Education Approach to Combat Covid-19 Pandemic Effect. RSP Science Hub, 2(7), 131135. https://doi.org/10.47392/IRJASH.2020.77

Martinez Jr, R. R., Williams, R. G., \& Green, J. (2019). The Role of School Counselors Delivering a Trauma-Informed Care Approach to Supporting Youth in Foster Care. Professional School Counseling, 23(1), 2156759X2094774. https:// doi.org/10.1177/2156759X20947747

McInerney, M., \& McKlindon, A. (2014). Unlocking the Door to Learning: TraumaInformed Classrooms and Transformational Schools. Retrieved from https:// www.elc-pa.org/resource/unlocking-the-door-to-learningtrauma-informed-classrooms-and-transformational-schools/

Mustika, M. B., \& Objantoro, E. (2020). Pemanfaatan Mazmur 57 Dalam Konseling Krisis di Masa Pandemi COVID-19. Davar : Jurnal Teologi, 1(1), 18. Retrieved from http://ejournalsangkakala.ac.id/index.php/DJT/article/view/1

Okoli, C., \& Schabram, K. (2010). A Guide to Conducting a Systematic Literature Review of Information Systems Research. Communications of the Association for Information System, 37(43), 879-910. https:// doi.org/10.2139/ssrn.1954824

Oktawirawan, D. H. (2020). Faktor Pemicu Kecemasan Siswa dalam Melakukan Pembelajaran Daring di Masa Pandemi Covid-19. Jurnal Ilmiah Universitas Batanghari Jambi (JIUBJ), 20.

Pincus, R., Hannor-Walker, T., Wright, L., \& Justice, J. (2020). COVID-19's Effect on Students: How School Counselors Rise to the Rescue. NASSP Bulletin, 104(4), 241-256. https://doi.org/10.1177/0192636520975866

Pramana, C., Susanti, R., Ernawati, K., Darmawan, I. P. A., Miftah, M. Z., Lestyowati, J., ... Ramadhani, R. (2021). Distance Learning In Primary 
Schools During The Covid-19 Pandemic In Indonesia: Challenges, Solutions, And Projections. Turkish Journal of Computer and Mathematics Education (TURCOMAT), 12(4), 263-270. https:// doi.org/10.17762/turcomat.v12i4.502

Ramdhani, A., Ramdhani, M. A., \& Amin, A. S. (2014). Writing a literature review research paper: A step-by-step approach. International Journal of Basic and Applied Science, 3(1), 47-56. Retrieved from http:/ / digilib.uinsgd.ac.id/5129/

Ramdhani, M. A., \& Ramdhani, A. (2013). Verification of Research Logical Framework Based on Literature Review. International Journal of Basic and Applied Science, 3(2), 1-9. Retrieved from http:/ / digilib.uinsgd.ac.id/5127/

Rastrick, E. (2020). Teachers' Data Privacy While Teaching Online. Retrieved September 7, 2021, from Student Privacy Compass website: https:// studentprivacycompass.org/rastrick1/

St. Bonaventure University's. (2020, August 17). School Counselor: What Does the Future Hold? Retrieved September 8, 2021, from St Bonaventure University Online website: https://online.sbu.edu/news/school-counselor Strear, M., Duffy, H., \& Sunde, A. (2021). When Schools Go Dark, School Counselors Shine: School Counseling during a Global Pandemic. Brief. In American Institutes for Research. Washington: American Institutes for Research.

Tanti, N. S. (2021). Peran Guru BK Dalam Mengatasi Kesulitan Belajar Siswa DiMasa Pandemi Covid-19 Di MAN 1 Medan. Universitas Islam Negeri Sumatera Utara, Medan.

Wong, C. A., Ming, D., Maslow, G., \& Gifford, E. J. (2020). Mitigating the Impacts of the COVID-19 Pandemic Response on At-Risk Children. Pediatrics, 146(1), e20200973. https:/ / doi.org/10.1542/ peds.2020-0973

Ziomek-Daigle, J., Goodman-Scott, E., Cavin, J., \& Donohue, P. (2016). Integrating a Multi-Tiered System of Supports With Comprehensive School Counseling Programs. The Professional Counselor, 6(3), 220-232. https:// doi.org/10.15241/jzd.6.3.220 